\title{
Influence of Internal Scrap on Mechanical Properties of Selected Cobalt Alloys
}

\author{
Bartosz Dęsoł ${ }^{a}$, Renata Zapała ${ }^{a *}$, Paweł Pałka ${ }^{\text {b }}$ \\ ${ }^{a}$ AGH University of Science and Technology, Faculty of Foundry Engineering, Reymonta 23, 30-059 Krakow, Poland \\ ${ }^{\mathrm{b}}$ AGH University of Science and Technology, Faculty of Non-Ferrous Metals, Mickiewicza 30, 30-059 Krakow, Poland \\ *e-mail: zapala@agh.edu.pl
}

Received: 2 June 2017/Accepted: 18 September 2017/Published online: 9 November 2017

This article is published with open access at AGH University of Science and Technology

\begin{abstract}
This paper presents the results of mechanical tests carried out on two different commercially available cobalt alloys applied in dental prosthetics for the production of frame dentures. The test samples were obtained by the method of investment casting using as a charge pure primary materials and pure primary materials mixed with various additions of process scrap $(25,50$, and $75 \%$ ). The tests showed that the alloys could not reach the mechanical properties reported by the manufacturer in either case. In the case of the alloy without the addition of tantalum, the general conclusion was that both the plastic and strength properties decreased with increasing amounts of the introduced process scrap. The mechanical properties (mainly elongation) of the alloy containing Ta reached the highest values in the samples containing $75 \%$ of the process scrap. Examinations of fractures carried out by SEM have revealed their varied character - ductile or transcrystalline. All of the samples tested showed the presence of dendrites and solidification areas, with shrinkage porosity occurring in the internal sample zones.
\end{abstract}

\section{Keywords:}

cobalt alloy, mechanical properties, fracture, scrap

\section{INTRODUCTION}

Along with titanium alloys, nickel alloys and $\mathrm{Cr}-\mathrm{Ni}$ steels, cobalt alloys belong to the group of common metal alloys that are widely used in medicine. Almost a century ago, the United States introduced the first cobalt alloy with chromium and molybdenum to dental surgery. The minimum chromium and molybdenum content in the alloy was $25 \%$ and $4 \%$, respectively [1]. Contemporary cobalt alloys for biomedical applications are modifications of that alloy. In the as-cast state, the structure of cobalt alloys is comprised of the solid solution of chromium, molybdenum, and carbon in cobalt (and additionally, carbide precipitates) [2]. Occasionally, the $\mathrm{CoCr}$ phase may also appear in the alloy structure [3].

Cobalt alloys are characterized by satisfactory mechanical properties (e.g., elastic modulus); due to this fact, it is possible to manufacture products with thin walls and, as a consequence, lower weight [4]. The beneficial combination of high mechanical properties and relatively low manufacturing costs has opened a wide range of applications for cobalt alloys in dentistry, mainly for frame dentures, braces, and prostheses on latches, bolts, and locks [3].

Due to the intricate shape of these castings (including the numerous design modifications introduced to satisfy the individual biological needs of each patient and, additionally, the tendency of cobalt alloys to undergo the strengthening process during production), the implementation of serial production is not possible. Products cast from these alloys are made by the investment technique. The use of investment casting in the manufacture of prosthetic parts generates large volumes of process scrap, including gating systems, casting cones, and rejects. Manufacturers allow the possibility to use scrap as part of the charge, but it should be remembered that any scrap metal introduced to the charge can influence the strength properties of the cast parts (among others) [5-11]. Therefore, an attempt was made in this study to determine the mechanical properties of samples cast from cobalt alloys containing the addition of process scrap.

\section{TEST MATERIAL AND METHODOLOGY}

Two cobalt alloys used in dentistry for the manufacture of frame dentures were chosen for the study. The chemical composition of these alloys is shown in Table 1.

Table 1

Chemical composition of test alloys [12]

\begin{tabular}{cccccc}
\hline \multirow{2}{*}{ Alloy } & \multicolumn{5}{c}{ Chemical composition, } \\
wt.\% \\
\cline { 2 - 6 } & Co & Cr & Mo & Ta & Si \\
\hline A & 64.6 & 29 & 4.5 & - & - \\
\hline B & 62.0 & 30 & 5.5 & 1.2 & 1.2 \\
\hline
\end{tabular}


From the selected alloys, cylindrical specimens with diameter $\varphi=5 \mathrm{~mm}$ and length $l=80 \mathrm{~mm}$ were cast in a dental prosthetics laboratory. The charge was composed of pure primary materials (samples labeled A1 and B1) and pure primary materials mixed with the addition of process scrap introduced in different amounts (samples labeled A2-A4 and B2-B4). The percent content of the introduced process scrap is shown in Table 2.

Table 2

Percent content of process scrap added to test alloys

\begin{tabular}{ccc}
\hline Sample designations & $\begin{array}{c}\text { Content of process scrap } \\
\text { added to test alloys, } \\
\%\end{array}$ \\
\hline A1 & B1 & - \\
\hline A2_25 & B2_25 & 25 \\
\hline A3_50 & B3_50 & 50 \\
\hline A4_75 & B4_75 & 75 \\
\hline
\end{tabular}

From the investment cast rod-shaped test pieces, specimens were prepared for the examination of non-metallic inclusions and the performance of a static tensile test.

Specimens for the evaluation of non-metallic inclusions were after cutting, grinding, and polishing examined under a Neophot 32 light microscope at 400x magnification.

The mechanical properties of the selected cobalt alloys were determined in a static tensile test performed on an Instron 5566 testing machine. The specimens were stretched at room temperature at a constant strain rate of $10^{-4} 1 / \mathrm{s}$.

The fractures formed during specimen failure were examined under a JSM 7100F scanning electron microscope. The observations were conducted at magnifications ranging from 100 to $500 \times$.

\section{RESULTS AND DISCUSSION}

Figure 1 shows the non-metallic inclusions present in the examined alloys. The observed precipitates are characterized by different shapes (globular and irregular), different sizes, and an uneven distribution on the examined surfaces.

Studies carried out by light microscopy did not reveal any major influence of the process scrap content on changes in the morphology of the inclusions present in the test samples.

The results of the static tensile test have shown that failure of the specimens occurred at different points in the measurement area, irrespective of the amount of process scrap added to the examined material.

From the stress-strain curves plotted during tensile testing (see sample diagram in Figure 2), it follows that the tested materials have no yield point. a)

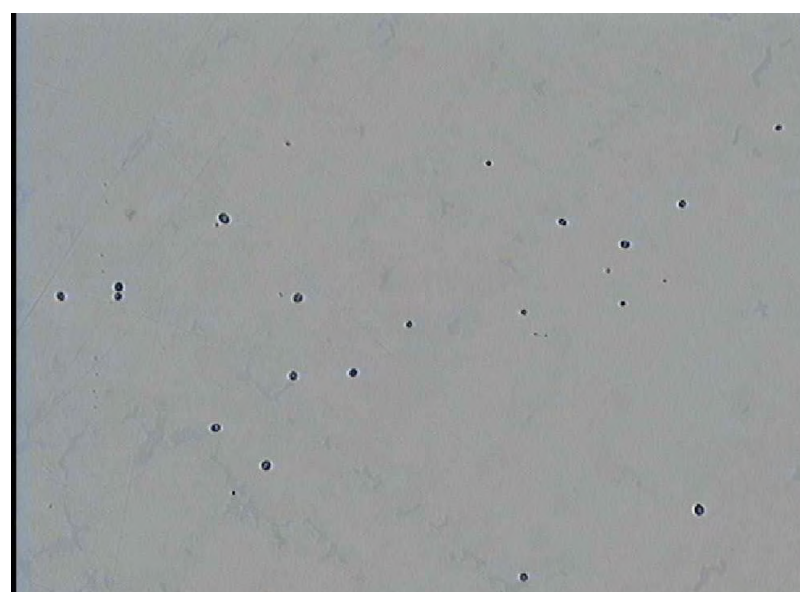

b)

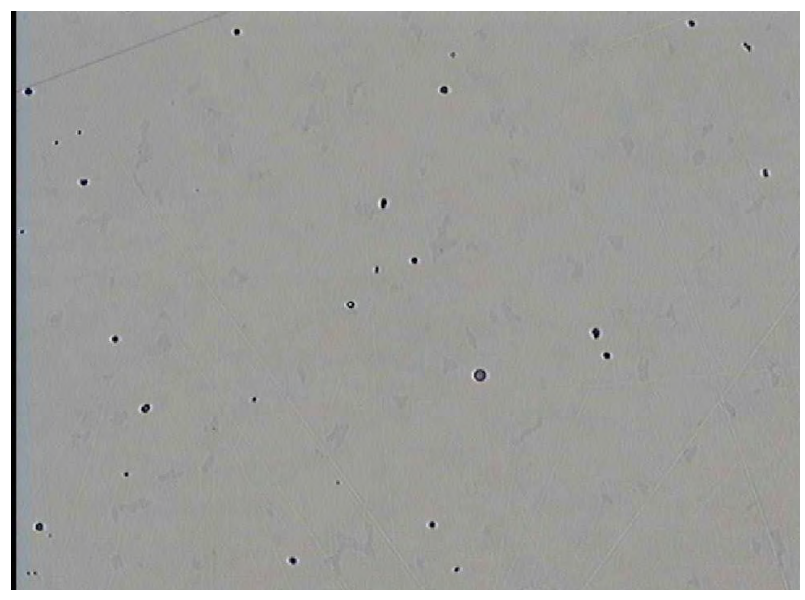

Fig. 1. Examples of non-metallic inclusions present in selected samples: sample A2_25 (a); sample B2_25 (b) light microscopy, magnification $400 \times$

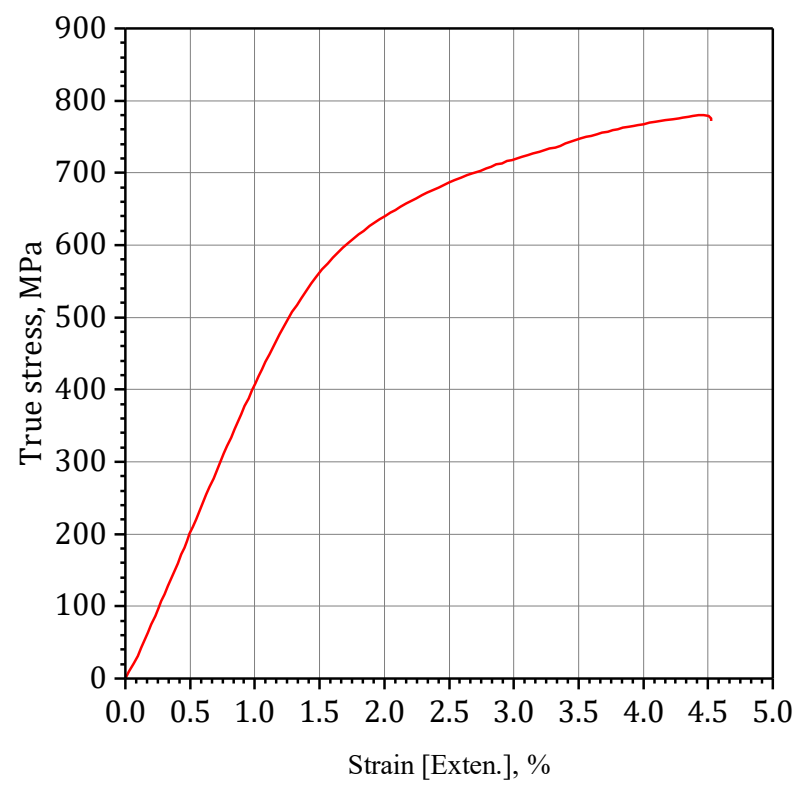

Fig. 2. Example of stress-strain curve plotted for investigated alloy 
a)

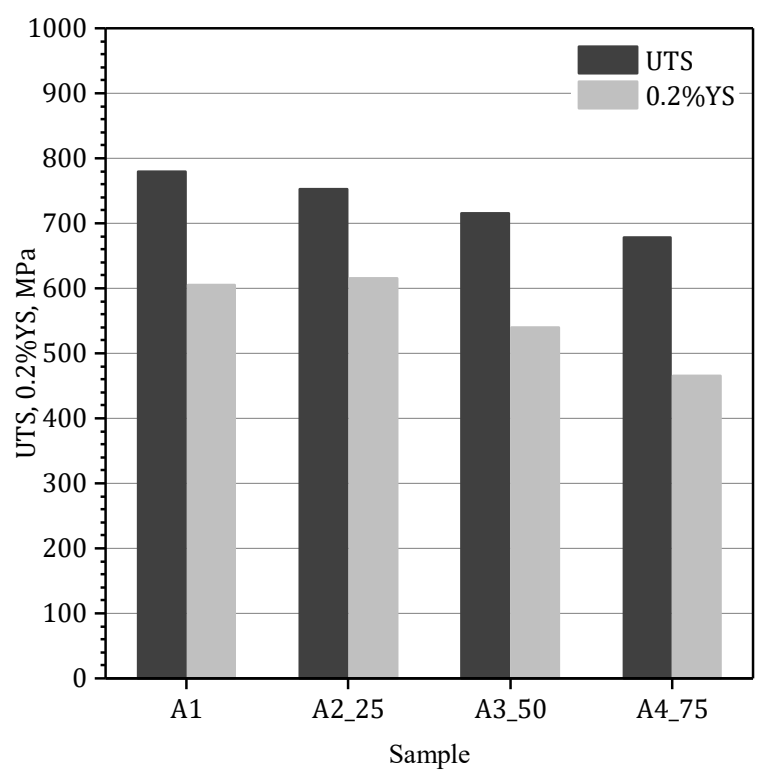

b)

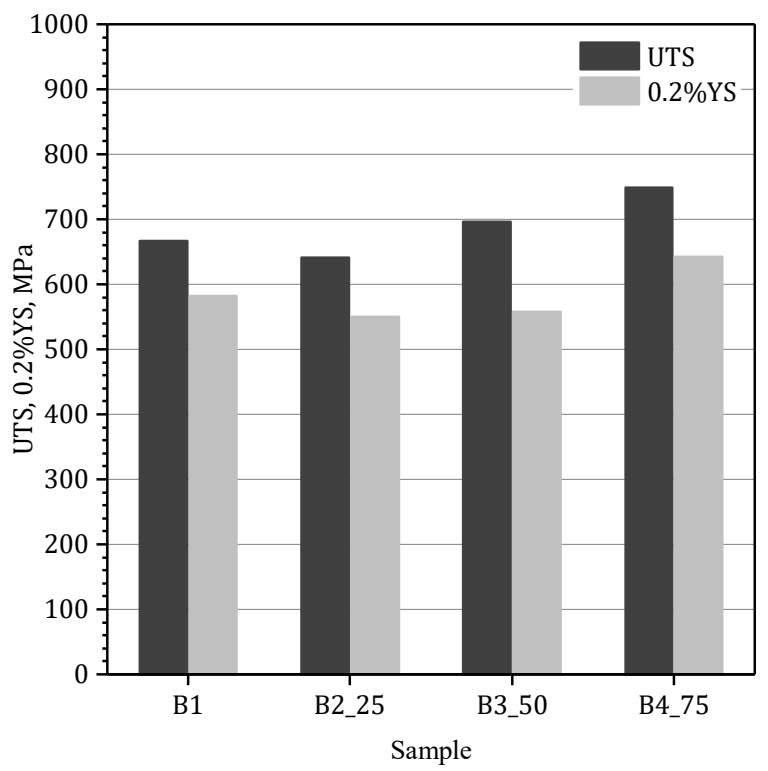

Fig. 3. Tensile strength UTS and yield strength $0.2 \%$ YS changing in tested alloys with changing scrap metal addition - Alloy A (a) and Alloy B (b)

Mechanical properties of the samples subjected to static tensile test are shown in Figures 3 and 4 and summarized in Table 3.

Table 3

Mechanical properties of the tested cobalt alloys

\begin{tabular}{cccc}
\hline Sample & $\begin{array}{c}\text { UTS, } \\
\text { MPa }\end{array}$ & $\begin{array}{c}\mathbf{0 . 2 \% Y S} \\
\text { MPa }\end{array}$ & $\begin{array}{c}\text { EL, } \\
\text { \% }\end{array}$ \\
\hline A1 & 779 & 605 & 2.58 \\
\hline A2_25 & 752 & 615 & 2.16 \\
\hline A3_50 & 716 & 540 & 1.66 \\
\hline A4_75 & 678 & 466 & 2.00 \\
\hline B1 & 667 & 582 & 0.75 \\
\hline B2_25 & 641 & 550 & 1.50 \\
\hline B3_50 & 696 & 558 & 2.57 \\
\hline B4_75 & 749 & 642 & 3.75 \\
\hline
\end{tabular}

The obtained mechanical properties of the alloys tested differ greatly from the values given in the literature [12].

Based on the obtained data (Fig. 3a), it was found that the mechanical properties of the tested materials decreased with an increasing scrap metal content in the alloy (the only exception is the yield strength obtained in the sample designated as A2_25).

With the introduction of $25 \%$ of process scrap, the tensile strength of the material designated as B was lower than the strength of the starting alloy (Fig. 3b). Samples containing $50 \%$ and $75 \%$ of process scrap in their composition were characterized by tensile strengths higher than the strength of the starting material.
The yield strength of the samples containing $25 \%$ and $50 \%$ of process scrap was lower than the yield strength of the starting material. The highest yield strength was achieved by the material designated as A4_75 containing $75 \%$ process scrap. Except for the alloy sample containing $75 \%$ process scrap, the elongation of the material designated as A decreased with an increasing content of the added scrap (Fig. 4). In contrast, the elongation of the material designated as B increased with an increasing content of process scrap. To explain the surprising impact of the increase in the amount of scrap introduced into the alloys (primarily Alloy B) on the improvement of tensile strength and elongation, further tests should be carried out.

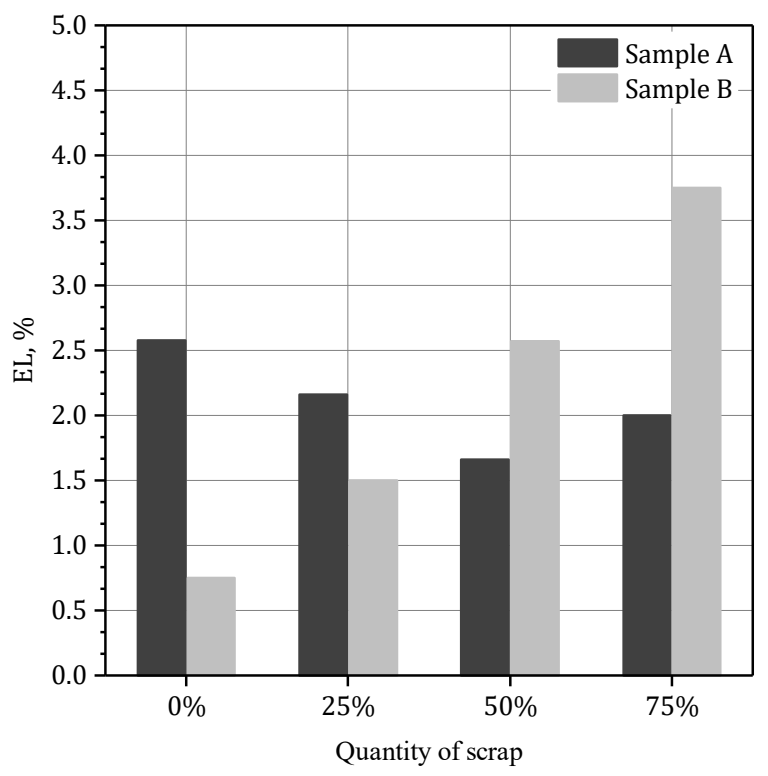

Fig. 4. Elongation changing in tested alloys with changing scrap metal addition 
a)
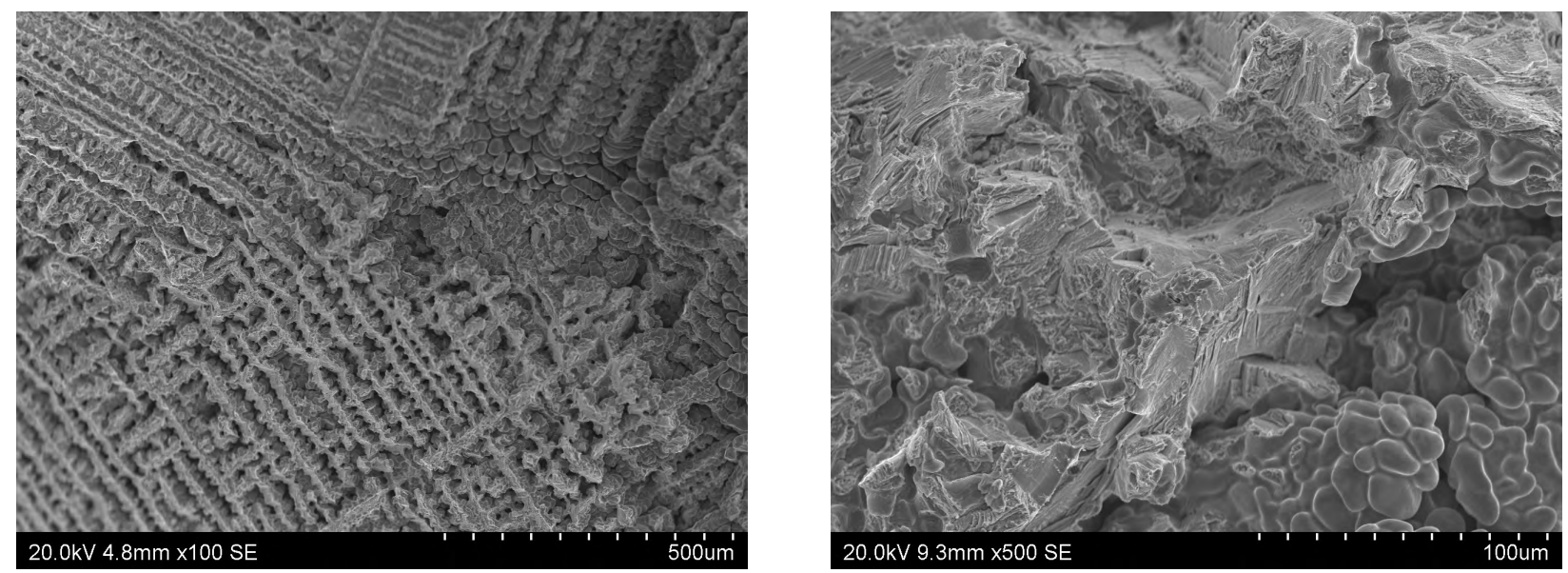

b)
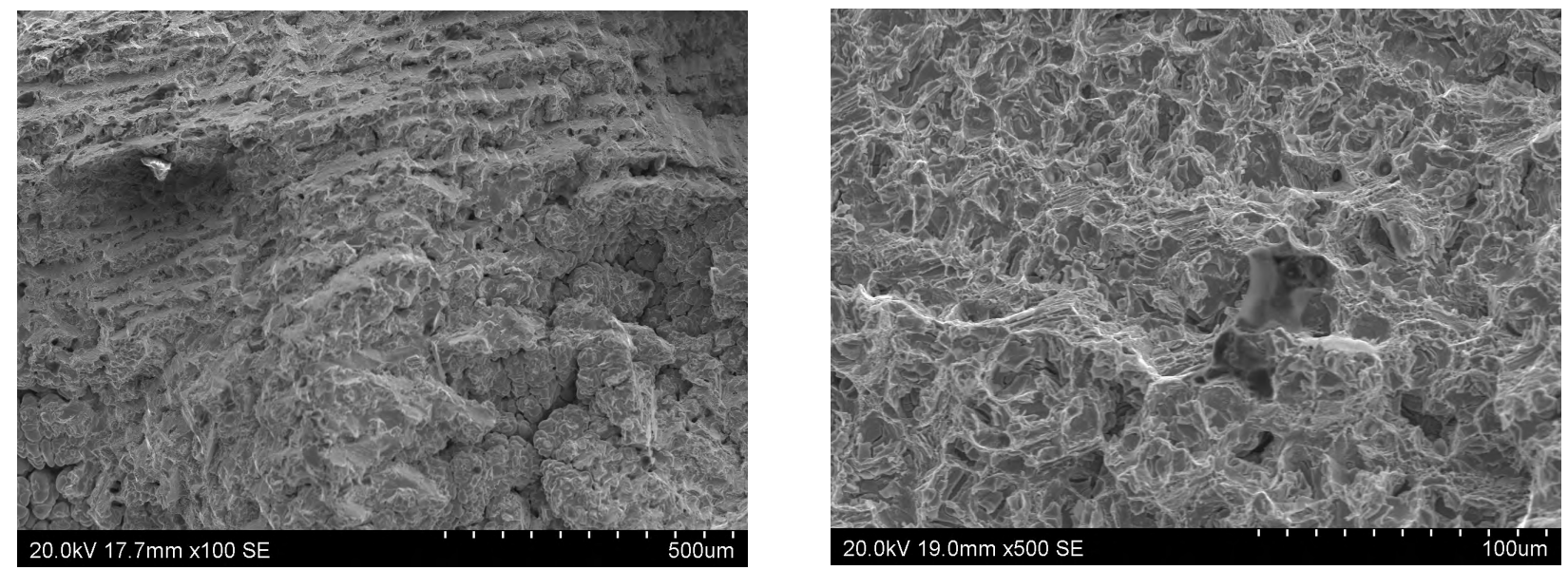

Fig. 5. Sample images of fractures formed in alloys during static tensile test - Alloy A (a) and Alloy B (b)

Figure 5 compares the SEM images of the fractures. Detailed examinations of the fractures formed during the static tensile test have revealed a dendritic pattern visible at low magnifications as well as shrinkage porosity occurring in the sample interior.

The observed fractures have different natures (ductile or transcrystalline). In some areas, sharp edges, large corrugations, and recesses occur.

\section{CONCLUSIONS}

The results of the studies lead us to the following conclusions:

1. In all of the tested materials, there are non-metallic inclusions characterized by different shapes and distributions.

2. From the results of a static tensile test, it follows that the tested material has no yield point.

3. The mechanical properties of the samples subjected to the static tensile test are definitely inferior to the values given by the manufacturer.

4. The values of UTS, $0.2 \% \mathrm{YS}$, and EL decreased in the tested Alloy A with an increasing content of process scrap.
5. Adding process scrap to the alloy designated as B makes the strength properties of this alloy decrease at first, followed by an increase. The elongation of the alloy designated as B increases with an increasing addition of process scrap. The maximum mechanical properties were obtained in the alloy designated as B4_75.

6. Factographic studies have revealed the presence of shrinkage porosity in the central part of the samples.

7. The examined fractures are of a ductile or transcrystalline nature.

\section{Acknowledgements}

The study was done as part of the bachelor's thesis of Dęsoł B. (2017). Badania właściwości mechanicznych stopów kobaltu. AGH University of Science and Technology.

\section{REFERENCES}

[1] ISO 6871-1:1994 Dental base metal casting alloys - Part 1: Cobalt-based alloys.

[2] Augustyn-Pieniążek J., Łukaszczyk A., Szczurek A. \& Sowińska K. (2013). Struktura i własności stopów dentystycznych na bazie kobaltu stosowanych do wykonywania protez szkieletowych. Inżynieria Materiałowa, 34(2), 116-120. 
[3] Surowska B. (2009). Biomateriały metalowe oraz połaczenia metal-ceramika w stomatologii. Lublin: Wydawnictwo Politechniki Lubelskiej.

[4] Marciniak J. (2013). Biomateriały. Gliwice: Wydawnictwo Politechniki Śląskiej.

[5] Surowska B., Beer K., Bienias J. (2011). Wpływ recyklingu na strukturę i właściwości wytrzymałościowe odlewniczego stopu kobaltu stosowanego w stomatologii. Acta Mechanica et Automatica, 5(3), 119-123.

[6] Al-Ali A.A. (2007). Evaluation of Macrohardness of Recasted Cobalt-Chromium Alloy. Al-Rafidain Dental Journal, 7(1), 111-117.

[7] Hajduga M., Puchalik A. (2009). Oszacowanie przydatności stopu Heraenium NA po przetopieniu w kontekście badań strukturalnych. Nowoczesny Technik Dentystyczny, 3, 56-60.

[8] Henriques G.E.P., Consani S., de Almeida Rollo J.M.D., Andrade e Silva F. (1997). Soldering and remelting influence on fatigue strength of cobalt-chromium alloys. The Journal of Prosthetic Dentistry, 78, 146-152.
[9] Majewski S., Opoka W., Gacek S. (1991). Właściwości stopu ćwiczebnego w zależności od postaci składników wyjściowych i wielokrotności odlewów. Protetyka Stomatologiczna, XLI(4), 192-198.

[10] Pierzynka R., Marciniak S., Klimek L. (2010). Wpływ liczby przetopień na właściwości mechaniczne stopu DUCINOX. Nowoczesny Technik Dentystyczny, 2, 22-24.

[11] Beer K., Walczak M., Surowska B., Borowicz J. (2012). Wpływ powtórnego przetapiania na właściwości mechaniczne i mikrostrukturę odlewniczego stopu kobaltu. Inżynieria Materiałowa, 33(5), 473-476.

[12] Nadolski M., Łagiewka M., Konopka Z., Zyska A., Golański G. (2015). The influence of remelting on the quality of prosthetic cobalt alloys. Archives of Foundry Engineering, 3, 53-58. 